Gut, 1966, 7, 612

\title{
Effects of oestrogens and progestogens on gastric secretion in patients with duodenal ulcer
}

\author{
S. P. PARBHOO 1 AND I. D. A. JOHNSTON ${ }^{2}$ \\ From the Department of Surgery, Queen's University, Belfast
}

EDITORIAL COMMENT Oestrogens control the symptoms of duodenal ulcer and probably increase the production of mucus in the stomach but they have no effect on the secretion of acid or pepsin. Progestogen by mouth also increases production of mucus and by intramuscular injection it lowers the gastric acid output.

In a controlled clinical trial Truelove (1960) showed that a daily dose of $1 \mathrm{mg}$. of stilboestrol given for six months had a beneficial effect on the course of duodenal ulcer in man. Further evidence that ovarian function may influence duodenal ulceration is provided by the fact that women are less liable to develop duodenal ulcer than men (White, 1951; Doll, 1952), although after the menopause the incidence rises (Borri, 1904); that the incidence of complications of duodenal ulcer in women increases after the menopause (Clark, 1953); and that pregnancy has a beneficial effect on the symptoms of duodenal ulcer (Clark, 1953).

To date, no clear evidence has emerged to account for these features. Animal experiments to assess the effect of oestrogens on gastric secretion have been contradictory and vitiated by species variations (Sandweiss, Saltzstein, and Farbman, 1938; Culmer, Atkinson, and Ivy, 1939; Ojha and Wood, 1950; Lozzio, Gagliardi, Biempica, and Royer, 1961; Antonsen, 1955; Singh and Shukla, 1959). In man, Baron (1963) has shown that women secrete less acid than men, which substantiates an earlier report by Vanzant, Alvarez, Eusterman, Dunn, and Berkson (1932). It has been claimed, however, that this difference is a function of lean body mass and not related to sex (Card, 1952). Baron (1964), however, was unable to demonstrate any correlation between body mass and gastric acid secretion.

Equally, studies of acid output by the stomach in pregnancy are inconclusive. Strauss and Castle (1932) reported reduced acid secretion in response to histamine and alcohol during pregnancy. Clark and Tankel (1954), on the other hand, were unable to

${ }^{1}$ This work was undertaken during the tenure of a British Council fellowship.

'Present address: Department of Surgery, University of Newcastleupon-Tyne. detect any change in the basal and augmented histamine output of acid and pepsin in nine women studied monthly throughout pregnancy although others found a reduction in the histamine-stimulated secretion during the second trimester (Murray, Erskine, and Fielding, 1957; Hunt and Murray, 1958).

This study therefore aims to determine in man with active duodenal ulceration the effect of oestrogens and progestogens on gastric acid and pepsin and mucus secretion.

\section{PATIENTS AND METHODS}

EFFECT OF ORAL OESTROGEN AND PROGESTOGEN Twentyfour patients with symptoms and radiological evidence of duodenal ulcer cooperated in this study. Patients were divided into three treatment groups, A, B, or C. Patients in group $A$ were given stilboestrol $5 \mathrm{mg}$. twice a day, those in group B received norethisterone $5 \mathrm{mg}$. twice a day, and those in group $\mathbf{C}$ were given two placebo tablets per day. Of 15 patients started on stilboestrol, five were withdrawn from the trial because of nausea and vomiting. All 10 patients who were given progestogen and all 10 patients given placebo successfully completed the course. There were thus 30 successful treatment periods involving 19 patients available for analysis. Where the same subject had more than one treatment the order of administration was varied. Studies of gastric secretion were done under control conditions in all patients before the beginning of treatment and subsequently at the end of each treatment period.

EFFECT OF INTRAMUSCULAR PROGESTOGEN A second study to investigate the effect of intramuscular progestogen on gastric secretion was carried out with the cooperation of five men with active duodenal ulceration. A dose of $125 \mathrm{mg}$. of 17ahydroxyprogesterone caproate was given after secretion studies had been completed and a further $250 \mathrm{mg}$. given five days later to maintain a high 
blood level of progestogen. Gastric secretion was measured again after 10 days of treatment.

EFFECT OF INTRAVENOUS OESTROGENS The third part of the study consisted of acute experiments which investigated the effect of giving large doses of oestrogens intravenously to nine duodenal ulcer patients secreting acid at a low rate in response to continuous intravenous infusions of histamine in doses of 0.04 to $0.09 \mu \mathrm{g}$. per kilogram of body weight per minute. Once secretion occurred at a steady rate six men were given $375 \mathrm{mg}$. of a conjugated equine oestrogen (Premarin) and the remaining three men received $20 \mathrm{mg}$. of oestriol dihemisuccinate. The total acid output was recorded every 15 minutes.

Gastric secretory studies were carried out by the method of Kay (1953) with the modification that the 14 or $16 \mathrm{f}$ Levin tube was placed in the pyloric antrum with the help of radiological control. The augmented histamine output of acid was measured from 15 to 75 minutes after the injection of histamine. The volume, visible mucus, and pH were measured and titration was carried out to neutrality ( $p \mathrm{H} 7$ to $7 \cdot 4$ ) with phenol red as indicator. Samples were stored at $-20^{\circ} \mathrm{C}$. for estimation of pepsin and nitrogen. Pepsin was measured by Hunt's (1948) modification of the Anson (1939) method but using spray-dried plasma as the substrate and a reference enzyme (Pepsin BP 1953, Hopkins and Williams Ltd.) to express the results in milligrams pepsin/ml. A modified micro-Kjeldahl Nesslerization method (King and Wootton 1956) was used to estimate the total gastric nitrogen. Gastric juice was inspected in a measuring cylinder and the amount of visible mucus recorded in arbitrary units of 0 to 5, 0 representing no visible mucus and 5 representing the situation where the entire secretion was of a gellike consistency.

\section{RESULTS}

TRIAL OF ORAL TREATMENT All patients were clinically assessed before and after therapy by one of us (S.P.P.). The overall assessment is summarized in Table I. Of 10 patients completing oestrogen

TABLE I

CLINICAL ASSESSMENT AFTER TREATMENT

\begin{tabular}{lcccc} 
Tablet & Improved & \multicolumn{2}{c}{ Unimproved } & Total \\
\cline { 3 - 4 } & \multicolumn{3}{c}{ No Change Worse } \\
\hline Stilboestrol & 7 & 2 & 1 & 10 \\
Dummy & 2 & 5 & 3 & 10 \\
Progestogen & 5 & 5 & 0 & 10
\end{tabular}

treatment, seven became asymptomatic and desired to continue their treatment. The most striking clinical impression in those who improved was the increased sense of wellbeing and a return, as well as an increase, in appetite. Five out of 10 patients improved while on norethisterone treatment. All patients gained weight during oestrogen therapy (Fig. 1). Since these weight changes were either maintained or increased

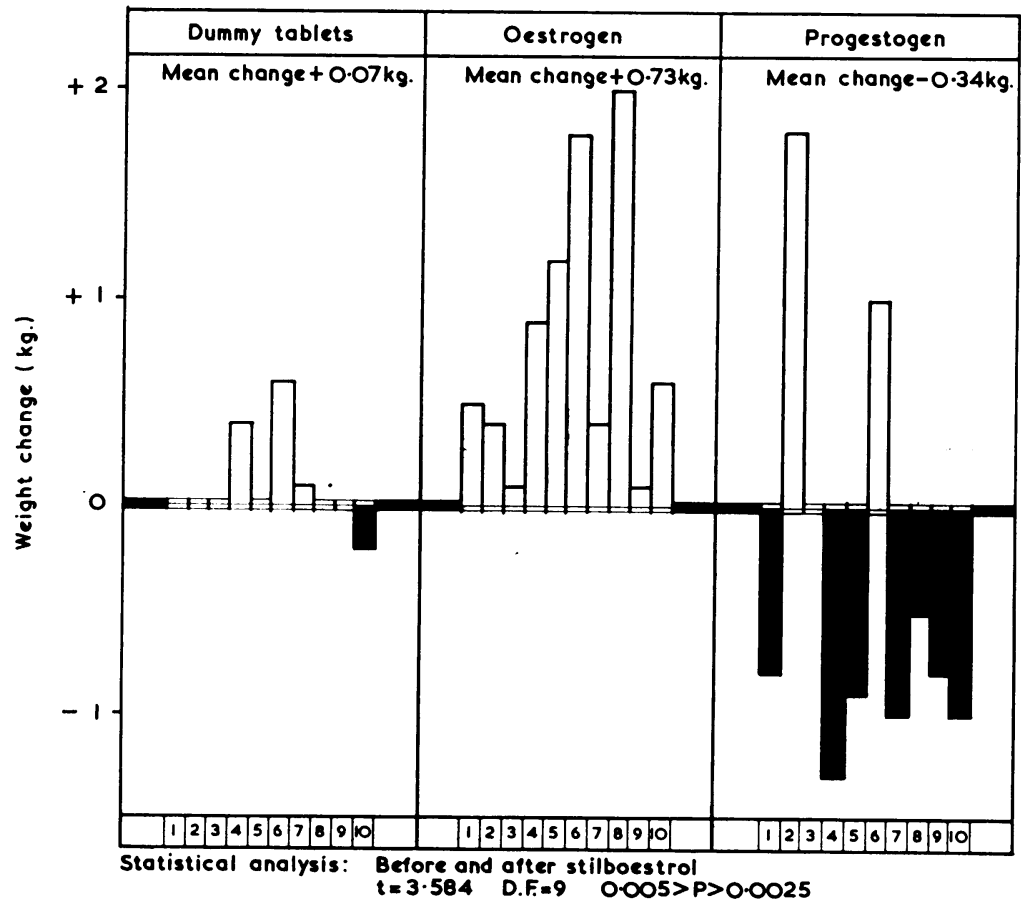

FIG. 1. Changes in body weight after one month. 
still further after two months of cessation of treatment, they were unlikely to be entirely due to salt and water retention. Weight changes in the other groups were unremarkable.

Five patients who complained of nausea and vomiting during treatment were replaced. All belonged to group A. Gynaecomastia or tenderness was not observed in this study. Patients were not told of the possible effect of these tablets on libido and no leading questions were asked to this effect during clinical reassessment. None of the patients volunteered information pertaining to libido.

One man on norethisterone developed severe itching of minor varicosities of the legs which had been present before treatment. Venous thrombosis did not occur.

Volume of gastric secretion No significant alteration occurred after stilboestrol or norethisterone treatment.
Acid output There was no significant change in the $p \mathrm{H}$ after stilboestrol or norethisterone. The basal and augmented histamine responses are shown in Table II. Neither show significant changes following treatment with either hormone.

Total gastric nitrogen The gastric nitrogen level increased following treatment with stilboestrol. Figure 2 shows the increase of nitrogen in the basal secretion in eight out of the 10 patients studied. Increased nitrogen levels were also noted in the posthistamine secretion following oestrogen and progestogen. A summary of the data is presented in Table III.

Secretion of mucus An increase in visible mucus occurred after both stilboestrol and norethisterone in the basal and post-histamine juices (Table IV).

Peptic activity The results are summarized in Table $\mathrm{V}$ which show no change in any treatment group.

TABLE II

EFFECT OF ORAL STILBOESTROL AND NORETHISTERONE ON THE BASAL AND AUGMENTED HISTAMINE SECRETION IN MEN WITH DUODENAL ULCER

\begin{tabular}{|c|c|c|c|c|c|c|c|c|c|c|c|}
\hline \multicolumn{6}{|c|}{ Basal } & \multicolumn{6}{|c|}{ Augmented Histamine } \\
\hline \multicolumn{3}{|c|}{$m E q . / H o u r$} & \multicolumn{3}{|l|}{$m E q \cdot / l$} & \multicolumn{3}{|c|}{$m E q . / H o u r$} & \multicolumn{3}{|l|}{$m E q . / l$} \\
\hline Before & After & Change & Before & After & Change & Before & After & Change & Before & After & Change \\
\hline \multicolumn{12}{|c|}{ Stilboestrol $(5 \mathrm{mg}$. b.d. $\times 30$ days $)$} \\
\hline $3 \cdot 20$ & 7.06 & +3.86 & $36 \cdot 8$ & $41 \cdot 8$ & +5.0 & $32 \cdot 25$ & $20 \cdot 51$ & $-11 \cdot 74$ & $97 \cdot 4$ & $126 \cdot 6$ & $+29 \cdot 2$ \\
\hline 1.03 & $1 \cdot 18$ & +0.15 & $29 \cdot 4$ & 31.9 & $+2 \cdot 5$ & $33 \cdot 11$ & $18 \cdot 43$ & $-14 \cdot 68$ & $124 \cdot 5$ & $105 \cdot 3$ & $-19 \cdot 2$ \\
\hline $4 \cdot 41$ & $5 \cdot 21$ & +0.80 & $41 \cdot 2$ & $47 \cdot 8$ & +6.6 & $21 \cdot 21$ & 28.41 & $\begin{array}{r}7.20 \\
+\quad 7\end{array}$ & $118 \cdot 5$ & 111.9 & -6.6 \\
\hline 1.62 & $3 \cdot 71$ & +2.09 & $27 \cdot 0$ & $30 \cdot 4$ & +3.4 & $21 \cdot 24$ & 25.97 & $+4 \cdot 73$ & $94 \cdot 8$ & $100 \cdot 7$ & $\begin{array}{r}5.9 \\
+\quad 5.9\end{array}$ \\
\hline 1.68 & 1.42 & -0.26 & $25 \cdot 5$ & 21.9 & $-4 \cdot 6$ & $30 \cdot 32$ & $24 \cdot 08$ & $-5 \cdot 24$ & 80.9 & $84 \cdot 2$ & $+3 \cdot 3$ \\
\hline $6 \cdot 33$ & $7 \cdot 60$ & $+1 \cdot 27$ & $56 \cdot 5$ & $66 \cdot 1$ & +9.6 & $27 \cdot 88$ & $24 \cdot 25$ & -3.63 & $136 \cdot 0$ & $131 \cdot 1$ & -4.9 \\
\hline $4 \cdot 44$ & $1 \cdot 59$ & $-2 \cdot 85$ & $66 \cdot 3$ & $35 \cdot 3$ & $-31 \cdot 0$ & 34.97 & $36 \cdot 54$ & +1.57 & $109 \cdot 6$ & $124 \cdot 7$ & $+15 \cdot 1$ \\
\hline 1.68 & 1.07 & -0.61 & $25 \cdot 5$ & $14 \cdot 3$ & $-11 \cdot 2$ & $30 \cdot 32$ & 30.62 & +0.30 & 80.9 & $90 \cdot 1$ & $\begin{array}{r}+9.2 \\
\end{array}$ \\
\hline 1.00 & 0.40 & -0.60 & $12 \cdot 2$ & $15 \cdot 4$ & $+3 \cdot 2$ & 15.69 & $11 \cdot 28$ & $-4 \cdot 41$ & 93.4 & $107 \cdot 4$ & +14.0 \\
\hline $2 \cdot 01$ & $5 \cdot 18$ & $+3 \cdot 17$ & 52.9 & $48 \cdot 4$ & $-4 \cdot 5$ & $46 \cdot 31$ & 42.44 & -3.87 & $130 \cdot 1$ & $121 \cdot 6$ & $-8 \cdot 5$ \\
\hline \multirow{2}{*}{\multicolumn{3}{|c|}{$\begin{array}{l}\text { Mean change } \quad+0.07 \\
t=0.96010 .20>p>0.15\end{array}$}} & & & $2 \cdot 10$ & & & -2.98 & & & +2.49 \\
\hline & & & $\mathrm{t}=0.55$ & $0 \cdot 30>$ & $0 \cdot 25$ & $t=1 \cdot 3$ & $0 \cdot 10>$ & 0.05 & $\mathrm{t}=0$ & $0.30>$ & 0.25 \\
\hline \multicolumn{12}{|c|}{ Norethisterone $(5 \mathrm{mg}$. b.d. $\times 30$ days $)$} \\
\hline $3 \cdot 20$ & 2.08 & $-1 \cdot 12$ & $36 \cdot 8$ & $24 \cdot 5$ & $-12 \cdot 3$ & $32 \cdot 25$ & $21 \cdot 35$ & -10.90 & $97 \cdot 4$ & $98 \cdot 4$ & $+1 \cdot 0$ \\
\hline 1.68 & $1 \cdot 52$ & -0.16 & $25 \cdot 5$ & 10.9 & $-14 \cdot 6$ & $30 \cdot 32$ & $28 \cdot 11$ & $-2 \cdot 21$ & 80.9 & $92 \cdot 8$ & +11.9 \\
\hline $2 \cdot 58$ & 3.66 & $+1 \cdot 18$ & $61 \cdot 4$ & $50 \cdot 8$ & -10.6 & $19 \cdot 12$ & $15 \cdot 34$ & -3.88 & $108 \cdot 0$ & $79 \cdot 9$ & $-38 \cdot 1$ \\
\hline 1.62 & $4 \cdot 00$ & $+2 \cdot 38$ & $27 \cdot 0$ & $35 \cdot 1$ & $+8 \cdot 1$ & $21 \cdot 24$ & 20.07 & $-1 \cdot 17$ & 94.8 & $100 \cdot 4$ & $\begin{array}{r}5.6 \\
+\quad 5\end{array}$ \\
\hline 0.79 & 0.26 & -0.53 & $16 \cdot 8$ & $6 \cdot 3$ & -10.5 & 20.50 & 9.74 & $-10 \cdot 76$ & $101 \cdot 0$ & $92 \cdot 8$ & $-8 \cdot 2$ \\
\hline $4 \cdot 23$ & 1.59 & $-2 \cdot 64$ & $20 \cdot 5$ & $13 \cdot 6$ & -6.9 & $29 \cdot 37$ & $35 \cdot 25$ & +5.88 & $106 \cdot 8$ & 99.9 & -6.9 \\
\hline 0.51 & 3.66 & $+3 \cdot 15$ & $15 \cdot 5$ & $44 \cdot 6$ & $+29 \cdot 1$ & 23.91 & $32 \cdot 20$ & +9.29 & 96.8 & $126 \cdot 8$ & +30.0 \\
\hline 0.15 & $2 \cdot 54$ & +2.39 & $10 \cdot 0$ & 22.9 & +12.9 & $12 \cdot 47$ & $16 \cdot 57$ & $+4 \cdot 10$ & $71 \cdot 7$ & $94 \cdot 2$ & +22.5 \\
\hline 0.56 & $0 \cdot 19$ & -0.37 & $43 \cdot 0$ & 19.0 & $-24 \cdot 0$ & $5 \cdot 53$ & $7 \cdot 54$ & +2.01 & $58 \cdot 3$ & 89.8 & $+31 \cdot 5$ \\
\hline 6.73 & $2 \cdot 47$ & $-4 \cdot 26$ & $81 \cdot 1$ & $36 \cdot 3$ & $-44 \cdot 8$ & $39 \cdot 46$ & $28 \cdot 30$ & $-11 \cdot 16$ & $126 \cdot 5$ & $100 \cdot 7$ & -25.8 \\
\hline \multirow{2}{*}{\multicolumn{2}{|c|}{$\begin{array}{l}\text { Mean change } \\
t=0.0011 \mathrm{p}>0.50\end{array}$}} & -0.001 & & & $-5 \cdot 20$ & & & $-0 \cdot 189$ & & & -0.39 \\
\hline & & & $\mathrm{t}=0.7$ & $0 \cdot 25>$ & $0 \cdot 20$ & $\mathbf{t}=0.7$ & $0 \cdot 25>$ & $0 \cdot 20$ & $\mathrm{t}=0.0$ & 0.488 & $>0.475$ \\
\hline \multicolumn{12}{|c|}{ Dummy tablet (one twice daily) } \\
\hline 5.06 & $4 \cdot 74$ & -0.32 & $57 \cdot 5$ & $51 \cdot 0$ & -6.5 & $31 \cdot 95$ & $34 \cdot 70$ & +2.75 & $111 \cdot 7$ & $112 \cdot 3$ & +0.6 \\
\hline $3 \cdot 20$ & 4.98 & $+1 \cdot 78$ & 36.8 & $45 \cdot 3$ & +8.5 & $32 \cdot 25$ & $27 \cdot 55$ & $-4 \cdot 70$ & $97 \cdot 4$ & 115.8 & +18.4 \\
\hline 1.03 & 2.04 & +1.01 & $29 \cdot 4$ & $40 \cdot 8$ & $+11 \cdot 4$ & $33 \cdot 11$ & 25.98 & $-7 \cdot 13$ & $124 \cdot 5$ & $126 \cdot 7$ & $\begin{array}{r}+2 \cdot 2 \\
+\end{array}$ \\
\hline $2 \cdot 58$ & $5 \cdot 84$ & $+3 \cdot 26$ & $61 \cdot 4$ & $66 \cdot 4$ & +5.0 & $19 \cdot 12$ & $22 \cdot 76$ & +3.64 & $108 \cdot 0$ & 94.4 & -13.6 \\
\hline $11 \cdot 03$ & 10.61 & -0.42 & $77 \cdot 1$ & $89 \cdot 2$ & $+12 \cdot 1$ & $24 \cdot 32$ & $24 \cdot 16$ & $-0 \cdot 16$ & $105 \cdot 3$ & $107 \cdot 4$ & $+2 \cdot 1$ \\
\hline $4 \cdot 44$ & 4.92 & +0.48 & $66 \cdot 3$ & $49 \cdot 7$ & -16.6 & 34.97 & $38 \cdot 36$ & +3.39 & $109 \cdot 6$ & $111 \cdot 2$ & +1.6 \\
\hline 1.00 & 0.35 & -0.65 & $12 \cdot 2$ & $14 \cdot 6$ & +2.4 & 15.69 & $17 \cdot 33$ & $+1 \cdot 16$ & 93.4 & $96 \cdot 3$ & +2.9 \\
\hline $2 \cdot 01$ & $3 \cdot 52$ & +1.51 & 52.9 & $49 \cdot 6$ & $-3 \cdot 3$ & $46 \cdot 31$ & $47 \cdot 43$ & $+1 \cdot 12$ & $130 \cdot 1$ & $138 \cdot 3$ & $\begin{array}{r}8 \cdot 2 \\
\end{array}$ \\
\hline $7 \cdot 68$ & $10 \cdot 44$ & $+2 \cdot 76$ & $63 \cdot 5$ & $66 \cdot 1$ & +2.6 & $41 \cdot 74$ & $39 \cdot 12$ & -2.62 & $139 \cdot 1$ & $132 \cdot 1$ & -7.0 \\
\hline $4 \cdot 44$ & $7 \cdot 72$ & $+3 \cdot 28$ & $66 \cdot 3$ & $70 \cdot 2$ & +3.9 & $34 \cdot 97$ & 38.03 & +3.06 & $109 \cdot 6$ & $110 \cdot 9$ & $+1 \cdot 3$ \\
\hline \multicolumn{3}{|c|}{$\begin{array}{l}\text { Mean change } \\
t=0.2510 .45>p>0.127\end{array}$} & $t=0.0$ & 0.495 & $\begin{array}{r}+1.95 \\
>0.49\end{array}$ & & $\ldots$ & +0.01 & $t=1$ & $15>$ & $\begin{array}{l}+1 \cdot 67 \\
.40\end{array}$ \\
\hline
\end{tabular}


TABLE III

CHANGES IN GASTRIC JUICE NITROGEN AFTER STILBOESTROL AND NORETHISTERONE TREATMENT

\begin{tabular}{|c|c|c|c|c|c|c|}
\hline \multirow[t]{2}{*}{ Treatment } & \multicolumn{3}{|c|}{ Basal Gastric Juice Nitrogen ${ }^{1}$} & \multicolumn{3}{|c|}{ Augmented Gastric Juice Nitrogen ${ }^{1}$} \\
\hline & Before & After & Change & Before & After & Change \\
\hline Placebo & $\begin{array}{l}0.60 \\
t=0.566 \\
0.30>p>\end{array}$ & ${ }_{5}^{0.57}=9$ & -0.03 & $\begin{array}{l}0.54 \\
t=0.465 \\
0.35>p\end{array}$ & ${ }_{0}^{D F}=9$ & -0.03 \\
\hline Stilboestrol & $\begin{array}{l}0.63 \\
t=2.869 \\
0.01>p>\end{array}$ & $\underset{05}{\mathrm{DF}}=9$ & +0.14 & $\begin{array}{l}0.50 \\
t=2.957 \\
0.01>p\end{array}$ & $\underset{05}{\mathbf{D F}}=9$ & $+0 \cdot 17$ \\
\hline Norethisterone & $\begin{array}{l}0.58 \\
t=1.757 \\
0.10>p>\end{array}$ & ${ }_{5}^{D F}=9$ & $+0 \cdot 12$ & $\begin{array}{l}0.43 \\
t=2.597 \\
0.025>p\end{array}$ & $\begin{array}{c}\stackrel{0.55}{D F}=9 \\
013\end{array}$ & $+0 \cdot 12$ \\
\hline
\end{tabular}

${ }^{1}$ Mean results in $\mathbf{g}$./litre.

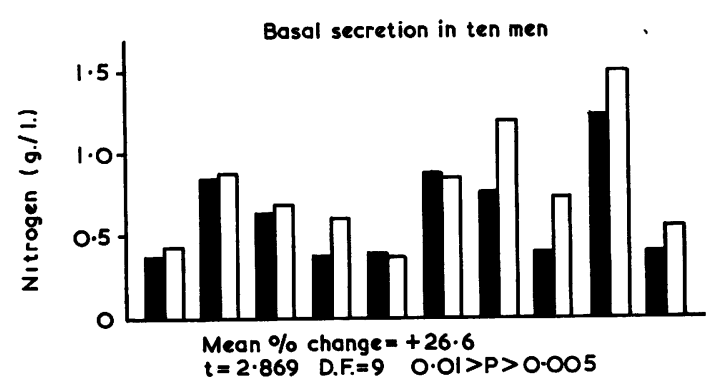

FIG. 2. Effect of stilboestrol on concentration of nitrogen in gastric juice (basal secretion).

TABLE IV

EFFECT OF STILBOESTROL AND NORETHISTERONE ON GASTRIC MUCUS SECRETION

\begin{tabular}{lll} 
Treatment & $\begin{array}{l}\text { Basal Mucus } \\
\text { Secretion }^{1}\end{array}$ & $\begin{array}{l}\text { Augmented Mucus } \\
\text { Secretion }^{1}\end{array}$ \\
\hline Placebo & +0.2 & -0.2 \\
& $\mathrm{t}=0.803 \mathrm{DF}=9$ & $\mathrm{t}=0 \mathrm{DF}=9$ \\
Stilboestrol & $0.25>\mathrm{p}>0.20$ & +0.8 \\
& +1.6 & $\mathrm{t}=2.759 \mathrm{DF}=9$ \\
Norethisterone & $\mathrm{t}=3.555 \mathrm{DF}=9$ & $\mathrm{t}=0.013>\mathrm{p}>0.01$ \\
& $0.005>\mathrm{p}>0.003$ & 0.013 \\
& +1.3 & +0.8 \\
& $\mathrm{t}=2.737 \mathrm{DF}=9$ & $\mathrm{t}=3.200 \mathrm{DF}=9$ \\
& $0.013>\mathrm{p}>0.01$ & $0.01>\mathrm{p}>0.005$
\end{tabular}

Mean change in arbitrary units (0-5)
EFFECT OF INTRAMUSCULAR PROGESTOGEN A slight decrease in the volume of gastric secretion was observed but this did not reach significance.

The $p \mathrm{H}$ of acid did not alter significantly nor was there any change in the basal output (Table VI). A significant fall in the post-histamine output was observed.

The increase in the total gastric nitrogen was not significant (Table VII).

The basal and post-histamine amount of mucus in the gastric juice increased significantly after treatment (Table VII).

As shown in Table VII, there was no significant change in peptic activity.

INTRAVENOUSLY ADMINISTERED OESTROGENS The results of this study in a single patient are shown in Figure 3. No significant change in acid output was observed, although with very low dosages of histamine (mean $0.046 \mu \mathrm{g}$. per kilogram body weight per min.) inhibition of $52 \%$ and $39 \%$ occurred in two out of three cases where the mean basal secretion in one hour was 5.04 mEq., mean histamine-stimulated secretion $13.07 \mathrm{mEq}$. per hour, and the mean post-oestrogen secretion over one hour was $8.68 \mathrm{mEq}$. In all cases on the higher dosage of histamine previously mentioned there were rises in

TABLE V

EFFECT OF ORAL STILBOESTROL AND NORETHISTERONE AND DUMMY TABLETS ON PEPTIC ACTIVITY

\begin{tabular}{|c|c|c|c|c|}
\hline \multirow[t]{2}{*}{ Tablet } & \multicolumn{2}{|c|}{ Basal peptic Activity (mg. pepsin/ml.) } & \multicolumn{2}{|c|}{ Augmented Peptic Activity (mg. pepsin/ml.) } \\
\hline & Before & After & Before & After \\
\hline Placebo & $\begin{array}{l}6.81(9)^{1} \\
t=1.073 \\
0.20>p>0.15\end{array}$ & $7 \cdot 07$ (9) & $\begin{array}{l}2.79(10) \\
t=0.334 \\
0.40>p>0.35\end{array}$ & $3 \cdot 32(10)$ \\
\hline Stilboestrol & $\begin{array}{l}7.64(9) \\
t=0.917 \\
0.20>p>0.15\end{array}$ & $7.93(9)$ & $\begin{array}{l}3.21(10) \\
t=0.957 \\
0.20>p>0.15\end{array}$ & $3.52(10)$ \\
\hline Norethisterone & $\begin{array}{l}8.24(7) \\
t=0.672 \\
0.30>p>0.25\end{array}$ & $7 \cdot 76(7$ & $\begin{array}{l}2.83(10) \\
t=0.837 \\
0.25>p>0.20\end{array}$ & $3.43(10)$ \\
\hline
\end{tabular}




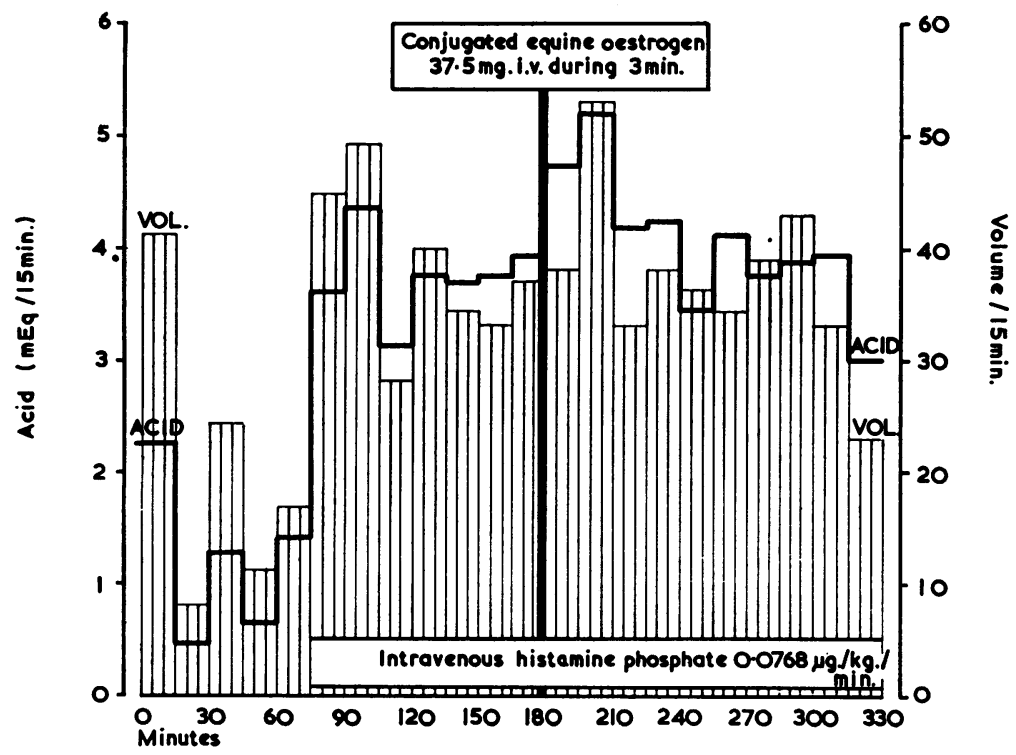

FIG. 3. Effect of IV oestrogen on gastric acid secretion $(G$. McF. 37 yr. 8.5.63).

the acid output following conjugated equine oestrogen and oestriol dihemisuccinate, but these were not statistically significant (Figs. 4 and 5).

\section{DISCUSSION}

The results of our investigations indicate that an elevation of the blood level of oestrogens has no effect on the secretion of acid or pepsin by the stomach and are in agreement with previous clinical investigations (Albers, 1940; Kirsner, 1963).

These results are in conflict with those of Ojha and Venkatachalam (1951) who reported that daily doses of $10 \mathrm{mg}$. of stilboestrol reduced the 'free' acid output after 10 days using the fractional test meal. The replicability of this test is poor and interpretation of the results is difficult.

In contrast to these reports is the observation of Abrahamson, Church, and Hinton (1942) that the 'free' and 'total' output of acid rose in a group of men with chronic duodenal ulcer treated with oestrogens. It is of interest that all these patients showed

TABLE VII

EFFECT OF INTRAMUSCULAR PROGESTOGEN ON PEPTIC ACTIVITY, GASTRIC MUCUS, AND NITROGEN

\begin{tabular}{|c|c|c|c|c|}
\hline & \multicolumn{2}{|l|}{ Basal } & \multicolumn{2}{|c|}{ Augmented } \\
\hline & Before & After & Before & After \\
\hline $\begin{array}{l}\text { Peptic activity } \\
\text { (mg. pepsin/ml.) }\end{array}$ & $\begin{array}{l}7 \cdot 63 \\
6 \cdot 19 \\
5 \cdot 36 \\
8.93 \\
8 \cdot 20 \\
\text { Mean } \\
t=0 . C \\
0.50>\end{array}$ & $\begin{array}{c}5 \cdot 64 \\
9 \cdot 52 \\
4 \cdot 60 \\
8.92 \\
7 \cdot 70 \\
\text { nge }+\cdot 014 \\
>0.49\end{array}$ & $\begin{array}{l}5.90 \\
3.07 \\
1.00 \\
1.31 \\
4.16 \\
\text { Mean } c \\
t=0.0 \\
0.50>\end{array}$ & $\begin{array}{c}2.90 \\
2.01 \\
3.47 \\
2.44 \\
5.52 \\
\text { nge }+0.18 \\
\\
>0.49\end{array}$ \\
\hline Visible mucus & $\begin{array}{l}2 \\
1 \\
0 \\
0 \\
1 \\
\text { Mean } \\
t=3.5 \\
0.013\end{array}$ & $\begin{array}{c}2 \\
4 \\
2 \\
3 \\
5 \\
\text { nge }+2.4 \\
>0.01\end{array}$ & $\begin{array}{l}0 \\
0 \\
0 \\
0 \\
0 \\
\text { Mean c } \\
t=5.6 \\
0.003\end{array}$ & $\begin{array}{c}1 \\
2 \\
1 \\
1 \\
2 \\
\text { nge }+1.4 \\
>0.001\end{array}$ \\
\hline Total nitrogen (g./l.) & $\begin{array}{l}0.83 \\
0.68 \\
0.37 \\
0.37 \\
0.38 \\
\text { Mean } \\
t=0.8 \\
0.25>\end{array}$ & $\begin{array}{l}0.80 \\
0 \cdot 50 \\
0.74 \\
0.74 \\
0.80 \\
\text { ge }+0.1 \\
\text { p.20 }\end{array}$ & $\begin{array}{l}0.41 \\
0.68 \\
0.37 \\
0.37 \\
0.45 \\
\text { Mean } \\
t=1.6 \\
0.10>\end{array}$ & $\begin{array}{c}0.40 \\
1.00 \\
0.74 \\
0.55 \\
0.70 \\
\text { nge }+0.1 \\
0.05\end{array}$ \\
\hline
\end{tabular}

TABLE VI

EFFECT OF INTRAMUSCULAR PROGESTOGEN ON GASTRIC ACID SECRETION

Basal

\begin{tabular}{|c|c|c|c|c|c|}
\hline \multicolumn{3}{|c|}{$m E q . / H o u r$} & \multicolumn{3}{|l|}{$m E q . / l}$. \\
\hline Before & After & Change & Before & After & Change \\
\hline $\begin{array}{l}12 \cdot 12 \\
34 \cdot 70 \\
32 \cdot 25 \\
21 \cdot 24 \\
20 \cdot 50 \\
\text { Mean } c \\
t=4 \cdot 6\end{array}$ & $\begin{array}{l}10 \cdot 29 \\
29 \cdot 77 \\
25 \cdot 23 \\
18 \cdot 25 \\
13.61 \\
\\
\text { nge } \\
0.005>\end{array}$ & $\begin{array}{l}-1.93 \\
-4.93 \\
-7.02 \\
-2.99 \\
-6.89 \\
-23.76 \\
-4.752 \\
0.003\end{array}$ & $\begin{array}{r}88.5 \\
112.3 \\
97.4 \\
94.8 \\
101.0 \\
\text { Mean c } \\
t=0.2\end{array}$ & $\begin{array}{r}84 \cdot 3 \\
115 \cdot 8 \\
127 \cdot 4 \\
89 \cdot 0 \\
86 \cdot 1 \\
\\
196 \\
0 \cdot 45>\end{array}$ & $\begin{array}{l}-4.2 \\
+3.5 \\
+30.0 \\
-5.8 \\
-14.9 \\
+8.6 \\
+1.72 \\
0.40\end{array}$ \\
\hline
\end{tabular}




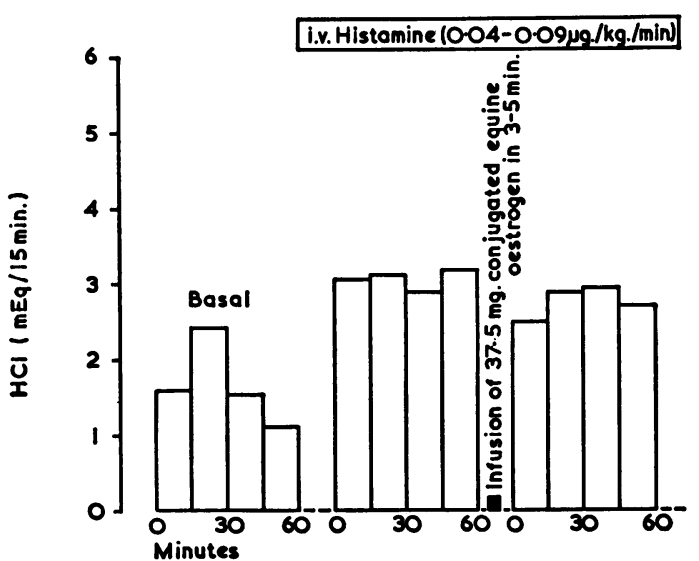

FIG. 4. Effect of IV oestrogen on gastric acid secretion (mean of six men).

some improvement during and immediately after treatment.

The protection afforded by pregnancy against duodenal ulceration and its complications in the presence of high blood levels of both oestrogens and progestogens must be due to factors other than changes in acid output. Interestingly enough, Kahlson, Lilja, and Svensson (1964) have shown protection against gastric ulceration during pregnancy in rats in the presence of raised acid output.

The resistance against digestion is provided by many factors, most of which are still poorly understood, including mucus, rapid epithelial turnover and migration, secretion of proteolytic ferments in the inactive form in the basal part of the gastric glands, and gastric urease, and it may be that oestrogens exert a beneficial influence on duodenal ulceration by altering the secretion of mucus. Oestrogens and progestogens are known to increase secretion of mucus in other parts of the body, such as the cervical canal, and further detailed studies of oestrogenic action on the components of gastric mucus are required. In this study the visible mucus was noted to increase after oestrogen treatment but its accurate measurement proved difficult. The total nitrogen content of the samples of gastric juice was used as a rough index of mucus content and a significant increase was observed after treatment. Since measurements were of total nitrogen, changes in gastric urease activity should not alter these results. No estimations of gastric juice or mucosal urease were made in this study.

The clinical benefit of oestrogens in the treatment of duodenal ulcer has been demonstrated once more but whether this is a practical method of

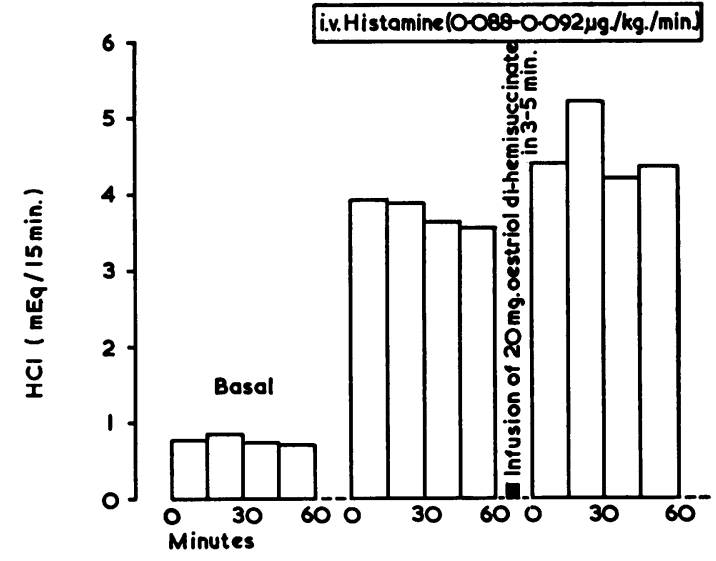

FIG. 5. Effect of IV oestriol on gastric acid secretion (mean of three men).

treatment is doubtful. The side effects in men of prolonged high doses of oestrogens are undesirable and the endocrine changes produced by these doses in women preclude their routine clinical use.

\section{SUMMARY}

A blind trial of treatment showed that oral doses of stilboestrol were effective in controlling the symptoms of duodenal ulcer but had no effect on the basal or augmented histamine secretion of acid or pepsin.

Intramuscular injections of the progestogen, 17ahydroxyprogesterone caproate, lowered the gastric acid output.

Intravenous infusions of oestrogens did not alter the rate of histamine-stimulated secretion of acid.

Total gastric nitrogen was increased after oestrogen treatment. It is suggested that this reflects an increased production of mucus following oestrogen therapy.

We are indebted to Professors H. W. Rodgers and R. B. Welbourn for their encouragement and permission to study patients under their care. We thank Mrs. M. Gilliland for technical assistance, Misses M. Davies and M. Simpson for secretarial help, and Messrs. G. Smith and R. Woods for the diagrams. We are most grateful to Dr. W. J. Tindall of Organon Laboratories Ltd. for supplies of stilboestrol and norethisterone tablets and oestriol-di-hemisuccinate, and to Dr. Dietrich of Schering A.G. Berlin for the 17 ahydroxyprogesterone caproate. We should also like to thank Dr. A. M. Connell for help in the preparation of the text.

\section{REFERENCES}

Abrahamson, R. H., Church, R., and Hinton, J. W. (1942). Hormone effects on the male gastroduodenal mucosa. Amer. J. med. Sci., 204, 809-823. 
Albers, H. (1940). Magensalzsäueresekretion nach Progynon. Geburtsh. u. Fraunenheilk., 2, 583-590.

Anson, M. L. (1939). The estimation of pepsin, trypsin, papain, and cathepsin with haemoglobin. J. gen. Physiol., 22, 79-89.

Antonsen, S. (1955). The influence of sex hormones on experimentally produced gastric ulcer in rats. Acta endocr. (Kbh.), 19, 203-208.

Baron, J. H. (1963). Studies of basal and peak acid output with an augmented histamine test. Gut, 4, 136-144.

- (1964). Peptic ulcer, gastric secretion and body build. Ibid., 5 , 83-85.

Borri, A. (1904). Über magengeschwüre im Klimakterium. Zbl. inn. Med., 25, 689-696.

Card, W. I. (1952). In The Principles and Practice of Medicine, edited by Sir S. Davidson, p. 635. Livingstone, Edinburgh. Cited by Baron (1963).

Clark, D. H. (1953). Peptic ulcer in women. Brit. med. J., 1, 1254-1257. and Tankel, H. I. (1954). Gastric acid and plasma-histaminase during pregnancy. Lancet, 2, 886-887.

Culmer, C. U., Atkinson, A. J., and Ivy, A. C. (1939). Depression of gastric secretion by the anterior pituitary-like fraction of pregnancy urine. Endocrinology, 24, 631-637.

Doll, R. (1952). Endemiology of peptic ulcer. In Modern Trends in Gastroenterology, pp. 361-379. Edited by F. Avery Jones, Butterworth, London.

Hunt, J. N. (1948). A method for estimating pepsin activity in gastric contents. Biochem. J., 42, 104-109.

- and Murray, F. A. (1958). Gastric function in pregnancy. J. Obstet. Gynaec. Brit. Emp., 65, 78-83.

Kahlson, G., Lilja, B., and Svensson, S. E. (1964). Physiological protection against gastric ulceration during pregnancy and lactation in the rat. Lancet, 2, 1269-1272.

Kay, A. W. (1953). Effect of large doses of histamine on gastric secretion of $\mathrm{HCl}$. An augmented histamine test. Brit. med. J., 2, 77-80.

King, E. J., and Wootton, I. D. P. (1956). Microanalysis in Medical Biochemistry, 3rd ed., pp. 17-19. Churchill, London.

Kirsner, J. B. (1963). Personal communication.

Lozzio, B. B., Gagliardi, O. P., Biempica, L., and Royer, M. (1961). Effects of pregnancy on gastric secretion in rats. Gastroenterology, 41, 126-128.

Murray, F. A., Erskine, J. P., and Fielding, J. (1957). Gastric secretion in pregnancy. J. Obstet. Gynaec. Brit. Emp., 64, 373-381.

Ojha, K. N., and Venkatachalam, K. (1951). Observations on the use of stilboestrol in the treatment of peptic ulcer. Gastroenterology, 18, 100-103.

— and Wood, D. R. (1950). The inhibitory effect of stilboestrol on gastric secretion in cats. Brit. J. Pharmacol., 5, 389-394.

Sandweiss, D. J., Saltzstein, H. C., and Farbman, A. (1938). The prevention or healing of experimental peptic ulcer in MannWilliamson dogs with the anterior pituitary-like hormone (antuitrin-S). Amer. J. dig. Dis., 5, 24-30.

Singh, G. B., and Shukla, R. C. (1959). Effect of gonadectomy on experimental peptic ulceration. Indian J. med. Res., 47, 287-293.

Strauss, M. B., and Castle, W. B. (1932). Studies of anaemia in pregnancy. I. Gastric secretion in pregnancy and the puerperium. Amer. J. med. Sci., 184, 655-662.

Truelove, S. C. (1960). Stilboestrol, phenobarbitone, and diet in chronic duodenal ulcer. Brit. med. J., 2, 559-566.

Vanzant, F. R., Alvarez, W. C., Eusterman, G. B., Dunn, H. L., and Berkson, J. (1932). The normal range of gastric acidity from youth to old age. Arch. intern. Med., 49, 345-359.

White, F. W. (1951). The incidence of gastroduodenal ulcer. In Peptic Ulcer, edited by D. J. Sandweiss, pp. 118-125. Saunders, Philadelphia. 